\title{
Model of Conflict Resolution Education Based on Cultural Value of "Pela" in Social Studies Learning
}

\author{
Samuel Patra Ritiauw \\ Elementary School Teacher Education Department \\ University of Pattimura \\ Ambon, Indonesia
}

\author{
Bunyamin Maftuh \\ Social Studies Education Departement \\ Indonesia University of Education \\ Bandung, Indonesia \\ Elly Malihah \\ Sociology Education Departement \\ Indonesia University of Education \\ Bandung, Indonesia
}

\begin{abstract}
Lack of students' knowledge about conflict resolution cause them to choose wrong conflict resolution (violence and students fighting) which also cause the occurrence of conflict phenomena among Maluku people, as the result of community fragmentation based on religion which is the effect of social conflict in 1999 in Maluku. This study uses Research and Development type, which aims to develop a model of conflict resolution education based on cultural value, to enhance the knowledge aspect of conflict resolution competence among students of the junior high school in Ambon City. The result of the study shows that model of conflict resolution education based on the cultural value of pela, give a good contribution to enhancing conflict resolution competence among students in Ambon City.
\end{abstract}

Keywords-Model of Conflict Resolution Education, Cultural Value of Pela, Social Studies Learning.

\section{INTRODUCTION}

The phenomena of conflict are often encountered in a plural society such as Indonesia. The occurrence of these phenomena is considered as a catastrophe for society who lives with love peace slogan. However, conflict only will disappear as the society themselves are disappearing. [1] [2] stated that "conflict can be defined as the relation between two people or more (individual and group) who have conflicted goal or there are different ideas among individuals which are developed into society." The different ideas and expectation among members of society had raised vertical and horizontal conflict in Indonesian society and particularly Maluku people. The horizontal conflict occurred in life of Maluku people in 1999, had caused thousand people dead, the destruction of people settlement and the break of social relation which had been built so far in Maluku [3][4][5][6][7][8] that: "the violent conflict in Maluku which is mostly concentrated in Ambon is one of the most terrible conflicts. This was occurred after the fall of Soeharto regime. That conflict results in almost 5000 people dead from 1999 until 2002 and evacuated the third of Maluku people from North Maluku.'

Besides the effect of social conflict such as revealed by Center for Humanitarian Dialogue above, one effect of social conflict in 1999 which occurred in Ambon City is prejudice and conflict reality, which dominate the attitude of groups who are in conflict. The prejudice is invoked by social situation, the past history, stereotype and ethnocentrism which become part of the culture in a certain group. In the other word, the social dynamic and development are very influenced by interethnic relations. According to [9], that: "prejudice as one' perception of someone or another group, and his/her attitude and behavior toward them." Meanwhile [10] [11] explained that prejudice is "bad attitude and can be though as a predisposition to perceive, think, underestimate and act which "against" or "approach" the others.

The prejudice occurred in social conflict reality in 1999 in Ambon City, is caused by segregation in society life such as segregation among public transportation drivers, segregation toward the choice and utilization of schools, teachers and employees distribution, and segregation of lectures location in University of Pattimura and State Polytechnic Ambon which is finally should choose the neutral location in the central of Ambon City. This segregation is based on the religion believed by the society members in Ambon City [12] [6] [13] [5] [14]. The high level of prejudice and there is no mutual trust in each group, and social segregation in a society based on religion, have worsened social interaction occurred in society in Ambon City. This reality consciously had resulted in violence culture among students. Violence culture among students occurred in students fighting from different schools in Ambon City. Based on data obtained from Polres of Ambon 
Island and Lease Islands, in the years of 2011-2015, there are 18 cases of students fighting.

To resolve the conflict among students, Social Studies education is thought as one step of strategy in developing students' conflict resolution competence, so in the future, when students face interpersonal or intergroup conflict, they are expected to be able to resolve that conflict constructively [15][16][17][18]. Constructive conflict resolution is in accord with the aim of Social Studies education to prepare students to become a good citizen, have intellectual, emotional, cultural and social ability [19][20][21]. The aim of Social Studies education furthermore is asserted by [22][19][23][24] that is developing students' potential in order to be sensitive to social problem occurs in society, have positive mental attitude to close all gaps, and skillful to solve each problem occurs in daily life. Therefore, students' conflict resolution competence is developed in Social Studies learning in class.

To enhance conflict resolution competence, Social Studies learning in class are related to cultural value "Pela" which is the identity of Maluku people in general and Ambon City in particular. Cultural value "Pela" is viewed as "Safety-Valve", [25] in minimizing the conflicts developed in the life of society in Ambon City. Pela has the natural characteristic to become cultural communication tool and also as mediation tool to construct collective knowledge and collective mind. In the other word, pela culture is a system of true brotherhood between two society or more, "Islam and Christian" in Maluku province, [26] [27[28]. Based on the background above, the purpose of this writing is to: find out the model of conflict resolution education based on cultural value pela (CREBCVP) in Social Studies learning to enhance the knowledge aspect of conflict resolution competence among Junior High School students in Ambon City.

\section{LITERATURE REVIEW}

\section{A. The Essence of Conflict}

Conflict can be defined as contradiction between two persons or more who have incompatible aims which are resulted in contradiction, disagreement, fighting, clash even war, but this conflict can also be defined as struggle for the needs, ideas, values and the goals of each individual which are incompatible or contradiction [29][30][31]. Conflict often defined also as "clash". Ref [32] said that "Change is shifted not anymore on ideological, political and economic conflict, but on civilization conflict."

In social studies, the term conflict and consensus are wellknown. In conflict approach, society has various conflicting interests, in another part of a consensus approach, society is integrated based on a value which is collectively agreed so society always in balance and harmonious [29]. Conflict can be violence and non-violence [17]. Conflict with violence can occur in society who does not have a basic consensus of foundation and goal of a society, and institutionalized regulation mechanism and conflict resolution. Conflict with non-violence occurs in society who have consensus and goal as well as an institutionalized regulation mechanism and conflict resolution, and it is a means to achieve agreement [33].

According to some experts, conflict actually can be differentiated by violence. The violence included action, speech, attitude or various structure and system which cause physical, mental, social and environmental damages or prevent someone to achieve his/her potential fully [30][34]. But on the other side, [25] stated that: Conflict not always negative but also positive in the case of helping to realize unity and awareness of living in social life. Conflict is needed because it is useful to make us aware of the problem and direct to the change needed, improve the solution, grow spirit, accelerate personal development, increase self-care, drive psychological maturity, and invoke pleasure [30]. From a micro level, interpersonal until group level, society and state, all forms of social relations, economic and power experience growth, change and conflict. Conflict is social life inheritance applied in various situations as consequence of disagreement, controversy, and contradiction among two people or more continually, [35] [29].

Ref [36] suggested that there are two kinds of conflict, namely intrapersonal conflict and interpersonal conflict. Intrapersonal conflict is conflict occurs within the individual $\mathrm{him} / \mathrm{h}$ erself, for example when the belief held by that individual is conflicted with the cultural value of society or his/her will is not suited with his/her ability. Intrapersonal conflict is psychological, if it cannot be handled well then it will disturb psychological health and mental hygiene of that individual. While interpersonal conflict is conflict occurs among individuals. This conflict occurs in each social environment, such as in family, a group of peers, school, community, and state. This conflict can be conflict among individuals and groups, both intragroup conflict and intergroup conflict. Ref [37] revealed that revealed that rooted conflict is a conflict which is derived from inside the state which combines two strong elements: strong identity factor based on the difference in race, religion, culture, language, etc which view injustice in economic, political and social resources distribution. Ref [38] stated that: social conflict always exists and always color all human interactions in the social structure.

\section{B. The Model of Conflict Resolution Education}

The Model of Conflict Resolution Education (CRE) is one educational model which aims to prepare students in facing conflict and resolving conflict constructively [39] [40] [41] [2] [7]. Besides being able to develop students' conflict resolution competence, CRE model also can develop and help teacher to manage active learning, to create peaceful class, to grow mutual respect which enable critical thinking and problem solving skill to be practiced well in learning [7][2][42][19][41]. The researchers had been developed CRE model among others by [16] and next the model with four approaches in conflict resolution education, namely: 1) Process curriculum approach: the approach in conflict resolution which provides certain time to give teaching related to conflict resolution topics (negotiation, mediation) in a 
subject, curriculum, and clear learning plan, 2) Mediation program approach is the program of conflict resolution education for selected students (cadre) which had been trained in conflict resolution. 3) A peaceable classroom approach is an approach which teaches students in a class about basic ability, principle, and the process of conflict resolution. In this approach, the program of conflict resolution learning is integrated into core subjects (citizenship, social studies, natural science, literary, art) and also into class management strategy. 4) Peaceable school approach; peaceable classroom approach is basic to build and realize peaceable school condition. This approach is comprehensive and use conflict resolution as a system to manage the class and school life. This approach not only focused on students, but also on all members of the school, such as teachers, counselors, staff $\&$ employees, school principal, and parents.

In accord with [16], [43] revealed three general approaches used in the program of conflict resolution education in school, namely: 1) The Cadre Approach is an approach which only trains conflict resolution skill toward the group of students. This approach is not applied broadly but focused on students in the certain class. 2) Comprehensive approach; this approach has a broad target and can be integrated into curriculum, vision-mission, policy and school program. This approach has some types of approach method as follow: a. Additional student training, b, Additional staff training, c. Curriculum infusion, and d. whole school programs. 3) Community Linked Program; this approach tries to apply conflict resolution learning to the community in general. In its implementation, it is applied in various spheres of community life such as organization, social, economic, governmental life, etc. This approach is claimed the most effective because it is mass in its implementation but also has disadvantage particularly if it is applied to the community who has not aware of the important role of conflict resolution.

Based on some approaches in applying conflict resolution education which had been explained above, the author uses peaceable classroom approach. This approach provides time to teach conflict resolution topics (negotiation, mediation) in Social Studies subject which is initiated by analyzing the curriculum used. After that, the author develops a learning plan, learning material, learning media, students' worksheet and learning evaluation (test) of CRE-BCVP which will be applied in class.

\section{The Cultural Value of Pela}

Philosophically, pela is not only defined as genealogical bounding. But more than this, pela is social bounding crossing tribal and religion boundaries (Islam and Christian) of each village/land which has pela. Ref [44] said that actually, pela characterize the contextual discourse (local genius) of Maluku society which gives direction about the mystery of human life who live and grow in Maluku which is anthropomorphic and social religious. Even the existence of Maluku people is an authentic evidence that tradition and religious imagination developed capable to produce and present the identity of Maluku people to understand and transform their unique historical existence through the culture pela. Therefore, the transformation of the values of Maluku culture should be deserved to have a place in society, in order that these values are not disappeared as a result of an identity crisis, lost of selfconfidence which certainly prioritizes global value than the local cultural value [45][46].

One institution which is the most responsible for the inheritance of cultural value pela in Maluku is education. As explained above, essentially education will comprise the act of educating, teach and train. That activity is implemented as an effort to transform the values. Then in its implementation, these three activities should be run integrally and continually and suited to students' development and their environment. Based on analysis of cultural value pela which is developed in Maluku society, then the values which will be transformed into this study are adapted from [47] [48] are as follow:

\section{1) Religious value (Respecting, Forgiving, Tolerating The Difference)}

This concept is about society appreciation toward some basic problems in the holy religious life so it becomes guidance for the religious behavior of that society. Essentially, this value actually is a value which has the truth with the strongest base compared to another value. This value derived from the highest truth from God. Inpela culture, the religious value emerged are:

- Mutual respect (tabea), respect the difference in tribe, religion, culture in Maluku society, respect the celebration of the religious holiday such as Idul Fitri (when Maluku society who are Muslim celebrate Idul Fitri, the duty to secure this celebration is done by them who are Christian, and the vice versa). If the community who are Christian visit the land whose community is Muslim, in which these lands have pela relation, then that community will be treated as the guest who should be respected in that land.

\section{2) Law obedience value (honesty, trust, justice)}

Law obedience is law awareness which generates the form of loyalty of community toward law values in behavior which obey the values of that law itself, and it can be seen and felt by members of the community. Law obedience value is manifested through 1) Sumpa (read: sumpah) or oath; Sumpapela usually found in hot event pela. The main purpose of this event is that in order that lands which have pela always remember of the sympathy had made and agreed to be done together without coercion. The core of all rituals of pela ceremony is in the formulation of sumpahpela because it is here that the binding oath is agreed by members of pela, that is, a community of villages with one pela, or their bounding with their ancestors [49]. 2). Justice; justice is the condition of moral ideal truth about one thing, both concerning the object or person or in the other word, justice is everything related to attitude and action in the relationships among people, justice contains a demand a person treat the others in accord with his/her right and duty. In Maluku community who uphold the values of pela, justice principle become the main priority in building relationships among villages which have pela. 3) 
The trust which is built when one of a community member in two custom villages (Negeri Makariki and Negeri Saleman) is when one of community member from these two villages forbid and scold, then the disaster will come to that person.

\section{3) Social value (Mutual cooperation, right, and status equality)}

Social value is everything considered as good and right, which is desired by the community. In order that social values can be created in the community, then social norm needs to be created with social sanctions. Social value is appreciation given by the community to everything which is good, important, lofty, suitable and has functional utility for development and the goodness of living together. The manifestation of social value among others are 1) Pattita; The eating tradition Patita is an event of eating together in intimate family ties by serving various kinds of food and traditional foods which are a unique characteristic of that region. Anyone who presents in that MakanPatita event is allowed to eat and enjoy the foods served as will without differentiating tribe, religion, culture, social status in that community. For Maluku community, makan Patita becomes an instrument to tighten brotherhood ties so wherever Maluku people live, the kinship keeps continually maintained. 2) Masohi; In Maluku people custom, mutual cooperation had been known from a long time ago by the name Masohi. Masohi can be defined as an act of cooperation or helping each other by exertion, both in largescale and small scale. This culture is described clearly when people build mosque and church in the community who has pela. The building process is initiated by tradition "Badati" (give voluntarily in order that the building process can run well).

\section{METHOD}

The research method used in this study is Research and Development which was developed by [50] with assumption is "a process used to develop and validate educational products" which was explained by Borg \& Gall as industrial based development model in which the finding of study used to design new product or procedure which is then systematically tested in field, evaluated and refined to fulfill the criteria of effectiveness, quality or standard. To get the right description about the usefulness of this model and to get the effective CRE-BCVP model and can be used in small scale or large scale, then the steps of research according to [50] is used which consist of ten steps of research and development implementation as a solution to find out the success of model used. The ten steps consist of 1) Research and information collecting, 2) Planning, 3) Develop product prototype, 4) Preliminary field testing, 5) Main product revision, 6) Main field testing, 7) Operational product revision, 8) Operational field testing, 9) Final product revision, and 10) Implementation and dissemination. To make easier researcher in developing the CRE-BCVP model, then researcher group three stages consisting of 1) Preliminary research/pre-survey, 2) Model development and implementation and 3) Final model validation testing.

\section{RESULT AND DISCUSSION}

\section{A. CRE-BCVP Model of Validation Test Result}

CRE-BCVP learning model which is developed in validation test of final model in a whole was not changed if compared with the stage of large-scale testing. However, there are some refinements in a model supporting system such as which material is simpler, so students more easily understand it. As for final model of validation test result is as follow:

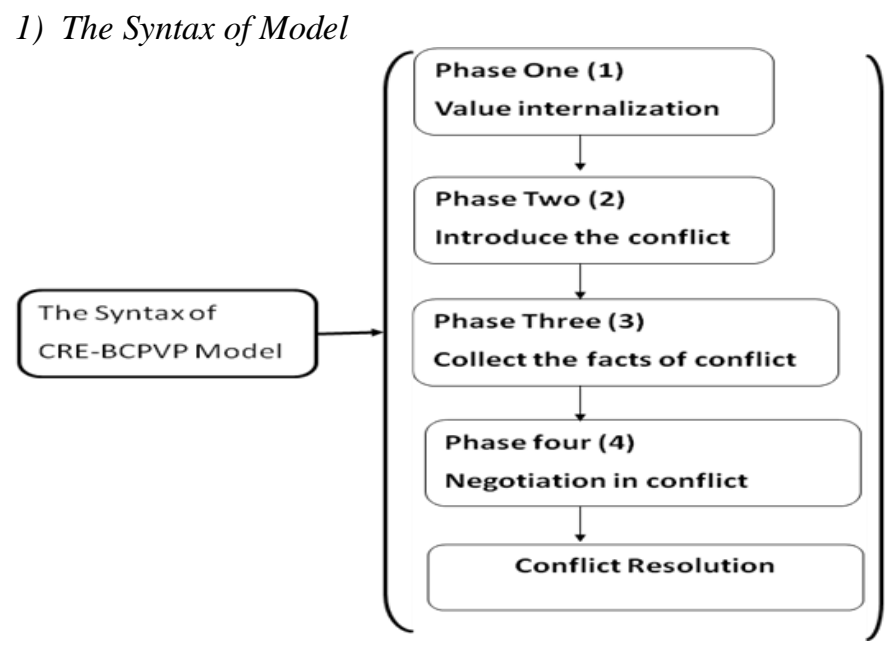

Fig 1. The Syntax of CRE-BCVP Model

Operationally, teacher and student activity during learning

\begin{tabular}{|c|c|c|}
\hline $\begin{array}{c}\text { Stage of } \\
\text { Learning }\end{array}$ & Teacher Activity & $\begin{array}{l}\text { Student } \\
\text { Activity }\end{array}$ \\
\hline \multirow{5}{*}{$\begin{array}{l}\text { Value } \\
\text { Internalization }\end{array}$} & Motivate students in learning & \multirow{5}{*}{$\begin{array}{l}\text { Student } \\
\text { notice, attend } \\
\text { to and do } \\
\text { what is } \\
\text { conveyed by } \\
\text { teacher }\end{array}$} \\
\hline & Ask students to sing Maluku songs & \\
\hline & $\begin{array}{l}\text { Ask students to listen to the story of } \\
\text { Maluku region history }\end{array}$ & \\
\hline & Connect the story/song to learning goal & \\
\hline & Explain the learning goal & \\
\hline \multirow[t]{5}{*}{$\begin{array}{l}\text { Introduce } \\
\text { conflict }\end{array}$} & $\begin{array}{l}\text { Find the conflict through the picture } \\
\text { related to learning material. }\end{array}$ & \multirow{5}{*}{$\begin{array}{l}\text { Pay attention } \\
\text { to teacher } \\
\text { explanation, } \\
\text { give example } \\
\text { and response } \\
\text { to the } \\
\text { problem } \\
\text { developed }\end{array}$} \\
\hline & $\begin{array}{l}\text { Explain the phenomena of conflict } \\
\text { occurred. }\end{array}$ & \\
\hline & Give the example of conflict & \\
\hline & Question-answer about conflict & \\
\hline & $\begin{array}{l}\text { Give reinforcement to the problem } \\
\text { developed }\end{array}$ & \\
\hline \multirow{4}{*}{$\begin{array}{l}\text { Collect the } \\
\text { facts of } \\
\text { conflict }\end{array}$} & Form cooperative group & \multirow{4}{*}{$\begin{array}{l}\text { Collect data } \\
\text { and } \\
\text { information, } \\
\text { and analyze } \\
\text { the problem }\end{array}$} \\
\hline & $\begin{array}{l}\text { Share the problem [dialogue of conflict } \\
\text { and the film BangunMaluku] }\end{array}$ & \\
\hline & Conduct investigation & \\
\hline & Do analysis of problem & \\
\hline \multirow{5}{*}{$\begin{array}{l}\text { Negotiation in } \\
\text { Conflict }\end{array}$} & Hold group discussion & \multirow{5}{*}{$\begin{array}{l}\text { Involved } \\
\text { actively in } \\
\text { discussion } \\
\text { and activity } \\
\text { related to } \\
\text { group [role } \\
\text { playing] }\end{array}$} \\
\hline & Presentation of group work result & \\
\hline & Response to another group work result & \\
\hline & Improve understanding among groups & \\
\hline & $\begin{array}{l}\text { Describe the values acquired in } \\
\text { discussion. }\end{array}$ & \\
\hline \multirow[t]{2}{*}{$\begin{array}{c}\text { Conflict } \\
\text { Resolution }\end{array}$} & $\begin{array}{l}\begin{array}{l}\text { Determine students' attitude toward } \\
\text { conflict }\end{array} \\
\end{array}$ & \multirow{2}{*}{$\begin{array}{l}\text { Determine } \\
\text { attitude, } \\
\text { skill, and } \\
\text { decision } \\
\text { derived from } \\
\text { cultural "Pela" } \\
\text { value "Po } \\
\text { and deflection } \\
\text { together. }\end{array}$} \\
\hline & $\begin{array}{l}\text { Determine skill which should be } \\
\text { possessed. } \\
\text { Formulate right decision } \\
\text { Make decision } \\
\text { Do reflection about the value which } \\
\text { should be acquired? } \\
\text { Do final evaluation }\end{array}$ & \\
\hline
\end{tabular}


process can be outlined as follow:

TABLE 1. THE ROLE OF TEACHER AND STUDENT IN LEARNING

2) The model of conflict resolution education based on the cultural value of "pela" capable to enhance students, knowledge aspect about conflict resolution.

Regarding students' knowledge aspect, the following is the description of the test result in measuring conflict resolution competence whose content is presented in Table 2.

TABLE 2. SMALL SCALE TESTING FOR KNOWLEDGE ASPECT OF CONFLICT RESOLUTION COMPETENCE

\begin{tabular}{|c|c|c|c|c|c|c|}
\hline \multirow{3}{*}{ Test } & \multicolumn{6}{|c|}{ Small Scale Testing } \\
\cline { 2 - 7 } & \multicolumn{3}{|c|}{} & \multicolumn{3}{|c|}{$\mathbf{2}$} \\
\cline { 2 - 7 } & $\boldsymbol{N}$ & Mean & Stdv & $\boldsymbol{N}$ & Mean & Stdv \\
\hline Pre-Test & 20 & 61.35 & 3.26 & 23 & 62.91 & 1.92 \\
\hline Post Test & 20 & 65.90 & 3.69 & 23 & 70.39 & 3.55 \\
\hline
\end{tabular}

Based on Table 2, it is seen that in small-scale testing 1, mean of 61.35 is increased in small-scale testing 2, which is 62.91. For small-scale posttest 1 , it obtains mean of 65.90 and increased in small-scale testing 2 with a mean of 70.39 . The increase in the stages of small-scale testing 1 and small-scale testing 2 is in the medium category. It because teachers are just started to test CRE-BCVP model which they not familiar with it, so learning process in the class had not run as expected in the implementation of CRE-BCVP model.

In this stage, the prior knowledge of teachers and students about Social Studies learning material had begun to build, but teachers and students are demanded to develop prior knowledge derived from Social Studies learning and related to cultural value Pela which will become reference in resolving the conflict, so needs to be improved at the stage of smallscale testing. The result of finding from small-scale testing 1 and 2 for knowledge aspect, then improved by providing learning sources such as students worksheet, picture media, film and another supporting facility in the form of focus media which enable students to reconstruct learning material developed, so it is expected that it is affected on students' knowledge aspect in large-scale testing. In large-scale testing, its implementation process is done in three stages, namely large-scale testing 1,2 and 3 .

TABle 3. LARGE SCAlE Testing For KNOWledge Aspect of CONFlict RESOLUTION COMPETENCE

\begin{tabular}{|c|c|c|c|c|c|c|c|c|c|}
\hline \multirow{3}{*}{ Test } & \multicolumn{10}{|c|}{ Large Scale Testing } \\
\cline { 2 - 11 } & \multicolumn{4}{|c|}{$\boldsymbol{M}$} & \multicolumn{4}{c|}{$\boldsymbol{2}$} & \multicolumn{3}{|c|}{$\mathbf{3}$} \\
\cline { 2 - 10 } & $\boldsymbol{N}$ & Mean & Stdv & $\boldsymbol{N}$ & Mean & Stdv & $\boldsymbol{N}$ & Mean & Stdv \\
\hline $\begin{array}{c}\text { Post } \\
\text { Test }\end{array}$ & 23 & 81.17 & 2.42 & 21 & 83.04 & 2.17 & 25 & 85.44 & 1.68 \\
\hline
\end{tabular}

Refer to Table 0.3, it is identified that in large-scale testing 1 , mean of 81.17 is obtained, whereas in large-scale testing 1 , mean of 83.04 is obtained. From large scale testing 2, followed by large-scale testing 3 , mean of the test result of conflict resolution competence in knowledge aspect is 85.44. This increase shows that teachers had begun to understand how to implement the CRE-BCVP model. It can be implemented well because before entering large-scale testing 1 , teachers are trained on how to develop Social Studies learning based on cultural value plain resolving the conflict occurred. The findings obtained when implementing the model in small-scale testing is trained again to teachers. Some priorities developed related to developing knowledge aspect among other are: 1) teachers are trained on how to find conflict in Social Studies learning material developed; 2) teachers are trained to make relatedness between the conflict found with cultural value pela as conflict resolution; and 3) teachers are trained for some concepts in conflict they had not understood well for example conflict escalation, controlling anger, and the right ways to resolve the conflict.

The result of accompanying intensely Social Studies teachers in the stage of large-scale testing had affected on the significant enhancement of students' conflict resolution competence in knowledge aspect. This can be seen from a comparison of posttest result in small-scale testing 2 in which test result mean of students' knowledge aspect achieve 70.39 while in large-scale testing 3, posttest mean of students achieve 85.44. Based on the result of knowledge aspect enhancement in large-scale testing 3, the researcher decides to continue doing validation test of the final model. It can be described that validation test of a final model is implemented in 3 different schools, namely: SMP F, SMP G, and SMP H, in which in each school researcher use two classes, namely one class as experiment class and one class as control class to implement the final model. The last stage in developing CREBCVP model is validation test of the final model which aims to enhance students' knowledge aspect of conflict resolution. This stage is designed by using pretest-posttest design experiment control group design. The enhancement of students' knowledge aspect in this stage can be seen in Table 4.

Table 4. Test Of Final Model Validation For KnOwledge Aspect OF CONFLICT RESOLUTION COMPETENCE

\begin{tabular}{|c|c|c|c|c|c|c|c|c|c|}
\hline \multirow{4}{*}{ Test } & \multicolumn{9}{|c|}{ Test of Final Model Validation } \\
\hline & \multicolumn{9}{|c|}{ Experiment } \\
\hline & \multicolumn{3}{|c|}{1} & \multicolumn{3}{|c|}{2} & \multicolumn{3}{|c|}{3} \\
\hline & $N$ & Mean & Stdv & $N$ & Mean & Stdv & $N$ & Mean & $S t d v$ \\
\hline $\begin{array}{l}\text { Pre- } \\
\text { Test }\end{array}$ & 26 & 73.88 & 2.14 & 31 & 76.06 & 2.08 & 28 & 75.82 & 1.58 \\
\hline $\begin{array}{l}\text { Post } \\
\text { Test }\end{array}$ & 26 & 85.76 & 1.92 & 31 & 87.35 & 1.56 & 28 & 90.03 & 0.96 \\
\hline \multicolumn{10}{|c|}{ Control } \\
\hline Test & $N$ & Mean & Stdv & $N$ & Mean & Stdv & $N$ & Mean & Stdv \\
\hline $\begin{array}{l}\text { Pre- } \\
\text { Test } \\
\end{array}$ & 33 & 61.90 & 3.46 & 27 & 62.44 & 2.37 & 24 & 64.20 & 2.43 \\
\hline $\begin{array}{l}\text { Post } \\
\text { Test }\end{array}$ & 33 & 65.24 & 3.72 & 27 & 67.37 & 2.37 & 24 & 67.04 & 3.16 \\
\hline
\end{tabular}

Table 4 shows test result of knowledge aspect of resolving conflict in a test of final model validation which involves two groups of learning, in which experiment group use CREBCVP model and control group use expository learning model. In a test of final model validation 1 , posttest mean for experiment control achieve 85.76 higher than a control group who achieve 65.24. The difference in a mean test of conflict resolution competence test for knowledge aspect also occur in 
a test of final model validation 2 , in which posttest mean for experiment group is 87.35 while for the control group is 67.37. It is identified also that for a test of final model validation 3, mean of test result for experiment group is 90.03 higher than a control group who obtain 67.04.

Based on all results from a test of final model validation, it is identified that there is the difference in test result mean of knowledge aspect of conflict resolution competence, in which experiment group is higher compared to control group. This because of experiment group is group whose teachers and students had been trained in the implementation of CREBCVP model, whereas in control group, the implementation of CRE-BCVP model had been developed also through expository learning. Therefore, it is affected on students' enhancement of knowledge aspect about conflict resolution. The difference in students' knowledge aspect between experiment group and control group, in which there is an enhancement in experiment group in a test of validation for those three stages. While in control group, there is no significant enhancement in knowledge aspect in the test of final model validation. This difference indicates that in average, experiment group who use CRE-BCPV model is better than a control group who use expository learning model. In specific, to see the difference in learning the outcome of knowledge aspect of conflict resolution, then statistic test is done by using t-independent test aided by SPSS version 19, with the result as follow.

\section{3) Test of two means difference for knowledge aspect of conflict resolution competence}

For analysis data in seeing the difference of two means in knowledge aspect then the t-independent test is used to compare two groups of data, in which experiment group use CRE-BCPV model and control group use expository model. Before the test is done by using t-independent test, then prerequisite test needs to be done in seeing whether data is distributed normally and homogenously. Based on the testing result, it is identified that data of knowledge aspect of conflict resolution competence is distributed normally and homogenously.

4) Test of two means difference in model validation 1

To test research hypothesis, the hypothesis formally is formulated as follow:

$\mathrm{H}_{\mathrm{o}}$ : There is no difference in knowledge aspect of conflict resolution between students who use CRE-BCPV model with students who use expository learning model in the model validation test 1 .

$\mathrm{H}_{1}$ : There is the difference in knowledge aspect of conflict resolution between students who use CRE-BCPV model with expository learning model in a test of model validation 1 .

By using independent sample t-test to see the difference between two means in which the test results is presented in Table 5.
TABLE 5.TEST OF POSTTEST DIFFERENCE FOR EXPERIMENT GROUP AND CONTROL GROUP IN MODEL VALIDATION 1

\begin{tabular}{|c|c|c|c|c|c|}
\hline & \multicolumn{3}{|c|}{$\begin{array}{c}\mathrm{t} \text {-test for equality of } \\
\text { means }\end{array}$} & Explanation & Decision \\
\hline Post_ValGab_Mod_1 & $\mathrm{t}$ & $\mathrm{df}$ & $\begin{array}{c}\text { Sig. } \\
(2- \\
\text { tailed })\end{array}$ & $\begin{array}{c}\text { Ho is } \\
\text { rejected }\end{array}$ & $\begin{array}{c}\text { There is } \\
\text { difference }\end{array}$ \\
\cline { 1 - 4 } & 25,511 & 57 & 0,000 & & \\
\hline
\end{tabular}

The criteria to make a decision by using $\alpha=0.05(5 \%)$ is if sig. (2-tailed) is smaller than $\alpha$ then $H_{o}$ is rejected and $H_{1}$ is accepted. Based on Table 06 it is seen that the value of significance 0.000 is smaller than 0.05 . It means that $\mathrm{H}_{\mathrm{o}}$ is rejected, which means that there is the difference in a test result of conflict resolution knowledge aspect between students who use CRE-BCVP model and students who use the expository model in the model validation test 1 .

\section{5) The test of two means difference in model validation 2}

In testing research hypothesis, it can be formulated the hypothesis as follow:

$\mathrm{H}_{\mathrm{o}}$ : There is no difference of conflict resolution knowledge aspect between students who use CRE-BCVP model and students who use expository learning model in the model validation test 2 .

$\mathrm{H}_{1}$ : There is a difference of conflict resolution knowledge aspect between students who use CRE-BCVP model and students who use expository learning model in the model validation test 2 .

Based on test result by using the t-independent test in seeing whether or not there is the difference in conflict resolution knowledge aspect between students who use CREBCVP model and students who use expository model, the test result can be seen in Table 6 .

TABLE 6. TEST OF POSTTEST DIFFERENCE FOR EXPERIMENT GROUP AND CONTROL GROUP IN MODEL VALIDATION 2

\begin{tabular}{|c|c|c|c|c|c|}
\hline & \multicolumn{3}{|c|}{$\begin{array}{c}\text { t-test for equality of } \\
\text { means }\end{array}$} & Explanation & Decision \\
\hline & $\mathrm{t}$ & $\mathrm{df}$ & $\begin{array}{c}\text { Sig. } \\
(2- \\
\text { tailed })\end{array}$ & $\begin{array}{c}\text { Ho is } \\
\text { rejected }\end{array}$ & $\begin{array}{c}\text { There is } \\
\text { difference }\end{array}$ \\
\cline { 2 - 4 } Post_ValGab_Mod_2 & 38,355 & 56 & 0,000 & \\
\hline
\end{tabular}

Based on Table 06, it is seen that the value of significance 0.000 is smaller than $\alpha=0.05(5 \%)$. This result indicates that $\mathrm{H}_{\mathrm{o}}$ is rejected, so it can be concluded that in the model validation test 2 , there is the difference in a test result of conflict resolution knowledge aspect between students who use CRE-BCVP model and students who use expository model. 
6) Test of two means difference in model validation 3

To see the difference in a test result of resolution conflict knowledge aspect in the model validation test 3 , then the research hypothesis is formulated as follow:

$\mathrm{H}_{\mathrm{o}}$ : There is no difference in conflict resolution knowledge aspect between students who use CRE-BCVP model and students who use expository learning model in the model validation test 3 .

$\mathrm{H}_{1}$ : There is a difference of conflict resolution knowledge aspect between students who use CRE-BCVP model and students who use expository learning model in the model validation test 3 .

To see the ability difference in conflict resolution aspect between students who use CRE-BCVP model and students who use expository model, then the t-independent test is used, but it is based on a prerequisite test of normal but not homogenous data, so it uses nonparametric test with the type of Mann-Whitney $U$ test. The result of data processing in answering research hypothesis is presented in Table 7 .

TABLE 7. TEST OF POSTTEST DIFFERENCE FOR EXPERIMENT GROUP AND CONTROL GROUP IN MODEL VALIDATION 3

\begin{tabular}{|c|c|c|c|c|c|}
\hline & \multicolumn{3}{|c|}{ Statistic } & Explanation & Decision \\
\hline \multirow{3}{*}{$\begin{array}{c}\text { Post_ValGab_Mod } \\
3\end{array}$} & $\begin{array}{c}\text { Mann- } \\
\text { Whitney } \\
\mathrm{U}\end{array}$ & $\mathrm{Z}$ & $\begin{array}{c}\text { Asymp. } \\
\text { Sig. (2- } \\
\text { tailed) }\end{array}$ & $\begin{array}{c}\text { Ho is } \\
\text { rejected }\end{array}$ & $\begin{array}{c}\text { There is } \\
\text { Difference }\end{array}$ \\
\cline { 2 - 4 } & .000 & - & 0,000 & \\
\hline
\end{tabular}

Refer to Table 7 in seeing whether or not there is the difference in conflict resolution competence test between experiment group who use CRE-BCVP model and control group who use expository model. From test result by using Mann-Whitney $U$, it is identified that the significance value of 0.000 is less than $\alpha=0.05$. This result shows that Ho is rejected and $\mathrm{H}_{1}$ is accepted, which means that there is the difference in a test result of conflict resolution aspect between experiment group and control group in model validation 3 . In a whole, the testing done both in the model validation test 1,2 , and 3, it is identified that there is the difference in mean of the test result in conflict resolution competence knowledge aspect between students who learn by using CRE-BCVP model and students who use expository model. To see the effectiveness of CRE-BCVP model then testing is done before by calculating $\mathrm{N}$-gain both for experiment group who learn by using CRE-BCVP model and control group who use expository model.

7) Test of $N$-gain mean $(<g>)$ difference for students' knowledge aspect of conflict resolution conflict

The aim to use $\mathrm{N}$-gain in this study is to know the category of enhancement ability of students' knowledge aspect of conflict resolution conflict, after using CRE-BCVP model and expository model. Table 08 below shows the result of $\mathrm{N}$-gain test both in experiment group and control group. $\mathrm{N}$-gain mean of test result for students' knowledge aspect of conflict resolution competence both experiment group and control group are presented in Table 9.

TABLE 8. N-GAIN OF FinAL MODEL VALIDATION TEST

\begin{tabular}{|c|c|c|c|}
\hline \multicolumn{4}{|c|}{ Test of Final Model Validation } \\
\hline Group & Test & $\mathrm{N}$-gain & Category \\
\hline \multirow{3}{*}{ Experiment } & 1 & 0,451 & Medium \\
\hline & 2 & 0,468 & Medium \\
\hline & 3 & 0,586 & Medium \\
\hline Mean & & 0,502 & Medium \\
\hline \multirow{3}{*}{ Control } & 1 & 0,081 & Low \\
\hline & 2 & 0,129 & Low \\
\hline & 3 & 0,084 & Low \\
\hline Mean & & 0,098 & Low \\
\hline
\end{tabular}

Based on Table 8 , it is seen that $\mathrm{N}$-gain means of final model validation test $1,2,3$ in experiment group is 0.502 in a medium category which is higher than the control group with $\mathrm{N}$-gain mean is 0.098 in the low category. This $\mathrm{N}$-gain test for final model validation shows that experiment group who learn by using CRE-BCVP model is better than a control group who use expository model. It means that CRE-BCVP model is effective to enhance students' learning outcome in knowledge aspect of conflict resolution based on cultural value "pela" in Social Studies learning.

\section{DISCUSSION}

\section{A. CRE-BCVP Model Capable to Enhance Students' Knowledge Aspect}

One of the important aspects of learning is helping students to acquire new knowledge and integrate it into the existing knowledge. Ref [51] revealed two kinds of knowledge, namely declarative knowledge and procedural knowledge. Declarative knowledge included fact, concept, and principle, whereas procedural knowledge included skills and processes. Students, who are learning declarative knowledge needs to be helped to relate it to their existing knowledge, organize that knowledge and make it become part of long-term memory. Whereas students who are learning new knowledge should be first confronted to model (steps) of that skill, then their skill is trained and practiced so they are able to face it easily.

Regarding with it, to enhance students' knowledge aspect of conflict resolution competence in the implementation of CRE-BCVP model, students are trained on how to find the conflict, conflicts sources, and the process of conflict, control anger, and make a decision and how to resolve the conflict based on cultural value pela. By students possessing prior knowledge about the conflict in Social Studies learning, then they can easily resolve the conflict occurred. Therefore, in Conflict Resolution Education teachers are not suggested to take the role as speaker in the learning process. Teachers should be closer to students, so students can acquire the knowledge in Social Studies learning. Ref [52] said that 
knowledge is skill and understanding of information and ideas. The goal of this knowledge is to help students to learn more about themselves, their physic and social world.

To understand the conflict in depth, then in knowledge aspect, students are trained on how to understand the essence of conflict occurred. Growing students' understandings of the essence of conflict in Social Studies learning can be initiated by some questions among others are: 1) what conflicts did you find in learning material? 2) What is a conflict? 3) What are the sources of that conflict? 4) How to resolve that conflict? By referring to four questions above, students are trained to classically find the way to analyze Social Studies learning material and express the opinion in accord with the knowledge possessed by students. Therefore, the result which is expected from enhancement of knowledge aspect is not limited only to instructional effects such as mastering learning material, but also nurturance effects such as possessing the ability, attitude, and habit required in students' daily life.

Students' attitude and habit as nurturance effects are manifested in critical thinking, mutual respect, discipline, responsibility, and cooperation in which all based on cultural value pela. If these aspects of this knowledge can be possessed by students, then it will effect on conflict resolution which set forth win-win problem solving in students' daily life. Ref [20] said that the real challenge when learning Social Studies is when students are out of school, in which students live in the community. This implies that learning Social Studies should empower students in all potencies, whether in knowledge, attitude, and skill. All these abilities can be manifested in the learning process through participation training and application in life.

In implementation of small-scale testing 1, there are some weaknesses found in implementation for example class was still very noisy, cultural value pela had not been developed in learning, teacher was more focused on teacher handbook, teachers' behavior which was not suited to conflict resolution learning such as threat students, students are more focused on students' worksheet, conflict resolution skill had not been developed in learning. These problems are one factor which causes CRE-BCPV model in small-scale testing is not stable. This because during Social Studies learning developed, teachers are more focused on teachers as the center of learning and students as learning material receiver, while teachers are rare to develop the use of innovative learning model.

In the learning process, a teacher tries to create and use various kinds of methods, in order that learning is not boring for students. A good teacher respects each effort done by students and respect students' work outcome and gives stimulation or encouragement to students in order that they are able to make and think while producing the work and creative thinking. Therefore, a teacher needs to use the varied method and learning media, and provide a various learning experience through interaction with content or learning material [53][54].

To solve some problems above, before entering broadscale testing, teachers are trained again through workshop activity. As for the aim of the workshop is to train teachers to make them more understand CRE-BCVP so in the implementation of broad-scale testing, teachers can develop learning in accord with learning plan which had been developed. Broad-scale testing in a whole can be implemented well if it compared with small-scale testing. The increase of students' knowledge aspect in broad-scale testing is improved. It means that CRE-BCPV model had been functioned well as guidance for learning designer and teachers in designing and implementing teaching learning activity. In addition, CRE-BCPV model has stages (syntax) which can be done by students under teacher guidance [55] [56]. Therefore, it can be concluded that CRE-BCPV can be implemented in the stage of final model validation testing to enhance students' knowledge aspect of conflict resolution competence. Figure 2 shows the development plot of students' knowledge aspect of conflict resolution competence.

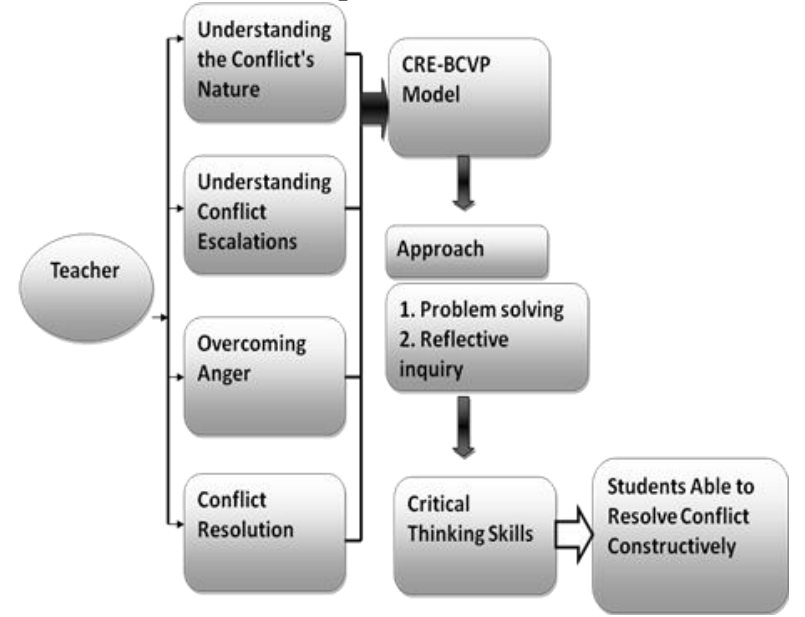

Fig 2. Development of Students' Knowledge Aspect of Conflict Resolution Competence

In developing students' knowledge aspect of conflict resolution, Social Studies teachers are demanded to understand 1) the essence of conflict; 2) the escalation of conflict; 3) anger; and 4) conflict resolution. These four components are developed in CRE-BCPV by using reflective inquiry approach and problem-solving. These two approaches which are developed by Social Studies teachers had been able to develop students' critical thinking skill. By possessing critical thinking ability, students are expected to be able to resolve the conflict occurred constructively, based on the knowledge possessed.

As for the final result of CRE-BCPV model development which can become reference for Social Studies teachers in implementing CRE-BCPV model more broadly, it can be seen in the figure below. 


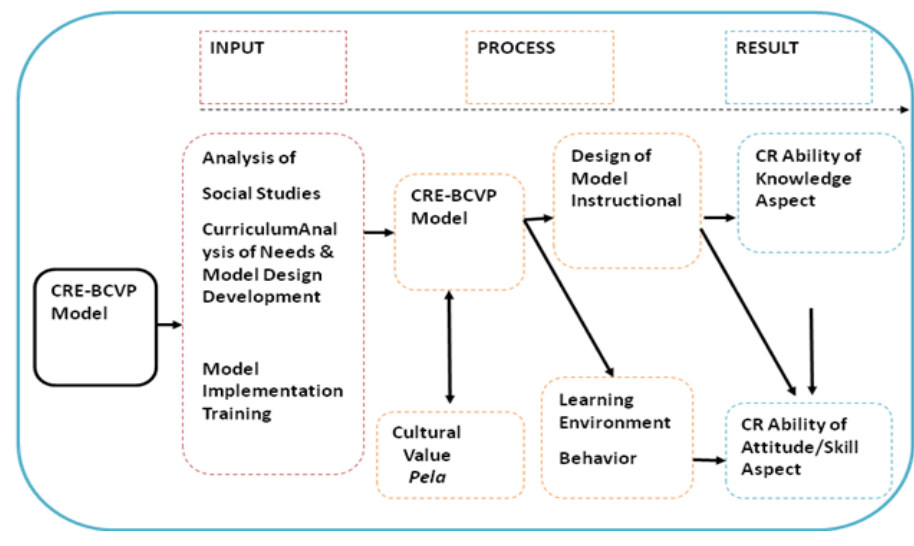

Fig 3. The Result of CRE-BCVP Model

The development of CRE-BCVP model in a whole had been able to enhance students' resolution conflict competence in knowledge, attitude and skill aspects. This enhancement accompanied by model improvement in stages from smallscale testing until model validation.

The development of CRE-BCVP model in a whole had been able to enhance students' conflict resolution competence in knowledge, attitude and skill aspect. This enhancement occurs along with model improvement in stages from smallscale testing to large-scale testing for model validation test. To implement CRE-BCVP model, then the first step which should be understood fully are curriculum analysis, needs analysis of model design development and training (introducing the model) to teachers before it is implemented for students in Social Studies learning. Good input had generated an intact CRE-BCVP model. To implement this model, then model instructional design, learning environment, teachers' behavior, students' behavior, should be developed well by Social Studies teachers in implementing CRE-BCPV model. By implementing the well CRE-BCVP model, then it had affected on the enhancement of knowledge aspect, attitude aspect and skill aspect of conflict resolution competence among $8^{\text {th }}$-grade students of Junior High School in Ambon City.

\section{CONCLUSION}

The result of the study shows that CRE-BCPV model capable to enhance students' conflict resolution competence in knowledge aspect. It can be seen from the mean score of pretest in validation testing 1 is 73.99 , validation testing 2 is 76.06 , and validation testing 3 is 75.82 . Whereas mean score of posttest in validation testing 1 is 85.76 , validation testing 2 is 87.35 and validation testing 3 is 90.03 . The achievement of mean score in validation testing of CRE-BCPV model for students' conflict resolution competence of knowledge aspect is corroborated by statistic test result by using Mann-Whitney $\mathrm{U}$ which identify that significance value of 0.000 is less than $\alpha=.005$ which presuppose that $H_{o}$ is rejected and $H_{1}$ is accepted. Therefore, there is the difference in a test result of conflict resolution between experiment group and control group in validation testing of CRE-BCVP model. The enhancement in conflict resolution competence of knowledge aspect can be seen also from students' abilities, namely 1) Understand the essence of conflict developed in Social Studies learning, 2) Understand the stage of conflict escalation and how students respond to conflict occurred, 3) Understand how the anger is invoked and how to control the anger invoked by conflict, and 4) Understand the alternatives of strategy taken in resolving the conflict occurred. The enhancement of students' knowledge aspect of conflict had affected on the enhancement of their attitude aspect and skill aspect of the conflict. Therefore, based on the explanation of result of study and discussion, it can be concluded that CRE-BCPV model is very effective in enhancing students' conflict resolution competence of knowledge aspect. The result of this study also confirms the finding which was published by [17], [15], [16], and [23].

\section{REFERENCES}

[1] Fisher, Mengelola Konflik: Keterampilan dan Strategi untuk Bertindak, The British Council, Jakarta, 2001.

[2] E. C. Papakitsos, K. Karakiozis, "Conflict Management Viasystemically Planned Peer Mediation", European Journal of Alternative Education Studies, Vol 1,Issue 2, 2016.

[3] Pelly, Usman, Menghindari Konflik Generasi Ketiga, Makalah Seminar Nasional Ikatan Himpunan Mahasiswa Sejarah Se Indonesia (IKAHIMSI), 2004.

[4] M. Manan, Gerakan Rakyat Melawan Elite,Yogyakarta: Resist Book, 2005.

[5] S. P. Ritiauw, "Peran Kepemimpinan Masyarakat dalam Penyelesaian Konflik Sosial di Kota Masohi Tahun 1999", Tesis, Sekolah Pascasarjana universitas Pendidikan Indonesai, 2008.

[6] T. Soumokil, Reintegrasi Sosial Pasca Konflik Maluku, Salatiga: UKSW Press, 2011.

[7] Romano, A Hirsch, S. F, Paczynska A, "Teaching about Global Complexity: ExperientialConflict Resolution Pedagogy in Higher Education Classrooms", Conflict Resolution Quarterly, 34 (2), 2017, pp 25-32.

[8] C. Buchanan, (Penyunting), Pengelolaan Konflikdi Indonesia-Sebuah Analisis Konflik di Maluku, Papua dan Poso, Centre for Humanitarian Dialogue, Switzerland, 2011.

[9] D. O. Sears, Psikologi Sosial, Jilid II (terj.), Jakarta: Erlangga, 1994.

[10] T. M. Newcom, Psikologi Sosial, Bandung: Diponegoro, 1985.

[11] R. Brown, Prejudice, Menangani Prasangka dari Perspektif Psikologi Sosial, Yogyakarta: Pustaka Pelajar, 2005.

[12] H.A. Kadir, "Sapa Bale Batu, Batu Bale Dia: Politik Revivalisme Tradisi Siwalima Orang “Ambon” Pasca Konflik”, Jurnal Lakon, 1 (1), 2012, pp 61-75

[13] T. D. Pariela, Damai Ditengah Konflik Maluku, Preserved Social Capital sebagai Basis Survival Strategy,[Disertasi Doktor Studi Pemba-ngunan, Universitas Kristen SatyaWacana], 2008.

[14] R. N. Ralahallo, "Kultur Damai Berbasis Tradisi Pela Dalam Perspektif Psikologi Sosial”, Jurnal Psikologi, 36 (2), 2009, pp 177-188

[15] K. Girard, and S. Koch, Conflict Resolution in the Schools: A Manual for Educators, San Francisco: Jossey-Bass, 1996.

[16] R. J. Bodine, D. K. Crawford, The Handbook of Conflict Resolution Education, A Guide to Building Quality Programs in Schools, San Francisco: National Institute For Dispute Resolution, 1998.

[17] M. Deutsch, P. T. Coleman, The Handbook of Conflict Resolution: Theory and Practice, San Francisco: Jossey-Bas Publishers, 2000.

[18] Rusminiati, "Model Pembelajaran Resolusi Konflik Berbasis Masalah Kontekstual Berpengaruh Terhadap Hasil Belajar IPS SiswaKelas V SD Gugus 1 A Biansemal", e-Journal Mimbar PGSD Universitas Pendidikan Ganesha, Jurusan PGSD, Vol 2., No 1, 2014 
[19] National Council for the Social Studies (NCSS), National Curriculum Standards for Social Studies: A Framework for Teaching, Learning, and Assessment (Silver Spring, MD: NCSS), Introduction, 2010.

[20] Sapriya, Pendidikan IPS Konsep Pembelajaran, Rosda, Bandung, 2012.

[21] D. W. Saxe, Historical Topics and Themes, Dalam Evans, R.W., \& Saxe, D.W.(eds.), Handbook on Teaching Social Issues, New York, National Council for the Social Studies, 1993.

[22] E. Maryani, dan E. Syamsudin, "Pengembangan Program Pembelajaran IPS untuk Meningkatkan Kompetensi Keterampilan Sosia", Jurnal Penelitian, 9 (1), 2009, pp 1-15

[23] B. Maftuh, Pendidikan Resolusi Konflik, Program Studi Pendidikan Kewarganegaraan, Sekolah Pascasarjana, Universitas pendidikan indonesia: Bandung, 2008.

[24] S. H. Hasan, Revitalisasi Pendidikan IPS dan Ilmu Sosial Untuk Pembangunan Bangsa, Ed, Suryadi Karim dan malihah eli, Inovasi pembelajaran IPS, Bandung: Rizqi Press dan FPIPS UPI, 2012.

[25] L. Coser, The Function Of Social Conflict, New York : Free Press, 1956.

[26] D. Bartels, Hubungan Pela di Maluku-Tengah Dan di Nederland, Suatu tindjauan singkat, Laporan Penelitian, Maluku, 1977.

[27] I. Misbach, Peran Permainan Tradisional yang Bermuatan Edukatif dalam Menyumbang Pembentukan Karakter dan Identitas Bangsa, Laporan Penelitian, Bandung: Universitas Pendidikan Indonesia, Tidak diterbitkan, 2006.

[28] T. Frans, "Wacana Tradisi Pela Dalam Masyarakat Ambon",Jurnal Bahasa Seni, 38, (2), 2010, pp 1-20

[29] H. A. Wani, "Understanding Conflict Resolution, International", Journal of Humanities and Social Science, 1 (2), 2011, pp 104-111

[30] T. Diez and E. Pia, Conflict and Human Rights: A Theoretical Framework, Sixth Framework Programme: University of Birmingham, 2007.

[31] A. E. Barsky, Conflict resolution for the helping professions (2nd ed.), Belmont, CA: Brooks/Cole CENGAGE Learning, 2007.

[32] F. Fukuyama and S. P. Huntington, The Future of The World Order, Masa Depan Peradaban Dalam Cengkraman Demokrasi Liberal Versus Pluralism, Yogyakarta:IRCisoD, 2005.

[33] J. Galtung, Theories of conflict, Definitions, Dimensions, Negations, Formations. Retrieved from: https://www.transcend.org/files/Galtung_Book_Theories_of_Conflict_si ngle.pdf, 2009.

[34] L. Balcells, P. Justino, "Bridging Micro and Macro Approaches to Civil Wars and Political Violence: Issues, Challenges, and the Way Forward", Journal of Conflict Resolution, 21 (3), 2014, pp 1-17

[35] Laia, B, "Rivalry and Revenge: Violence against Civilians in Conventional Civil Wars", International Studies Quarterly, 54 (2), 2010, pp291-313.

[36] M.P. Hunt, L. E. Metcalf, Rational Inquiry on society's closed areas, In Walter C. Parker (Ed) Educating the democratic mind, Albany, NY: State University of New York Press, 1996.

[37] P. Haris, and B. Reilly,(Penyunting), Demokrasi dan Konflik yang Mengakar: Sejumlah Pilihan Negosiator, Jakarta: International IDEA, 2000.

[38] A. Kuper, and J. Kuper, Ensiklopedialmu-ilmuSosial, Jilid 1, Jakarta: Rajawali Pers, 2000.

[39] B. Maftuh, Memperkuat Peran IPS dalam Membelajarkan Keterampilan Sosial dan Resolusi Konflik, Pidato Pengukuhan Jabatan Guru Besar dalam bidang Pendidikan Ilmu Pengetahuan Sosial Pada Fakultas Pendidikan Ilmu Pengetahuan Sosial-Universitas Pendidikan Indonesia, 2010.

[40] C. Finch, L. Wirtenan, Children and conflict in the classroom, retrieved from:

http://www.communityplaythings.com/resources/articles/behavior/childr enandconflict.html [Online, 10 Maret 2017], 2012.

[41] D. C. Jones, "Conflict Resolution for the Classroom", TEACH Journal of Christian Education, 9 (2), 2015, pp 1-4

[42] T. Campbell, Tujuh TeoriSosial: Sketsa, Penilaian, Perbandingan. Terjemahan, Yogyakarta: Kanisius, 1994.
[43] T. S. Jones, and Kmitta, School Conflict Management Evaluating Your Conflict Resolution Education Program (A guide for educators and evaluators), Ohio: ODE/OCDRCM, 2001.

[44] A. Wally, Maluku Baru: Bangkitnya Mesin Eksistensi Anak Negeri, Yogyakarta: Kanisius, 2005.

[45] A. McGrew, "Globalization and Global Politics,"dalamBaylis, John, dan Steve Smith (eds.), The Globalization of World Politics,Second Edition,Oxford: Oxford University Press, 2001.

[46] A. Giddens, The Consequences Of Modernity, Stanford University Press, 1990.

[47] K. Bertens, Etika, Jakarta: PT Gramedia, 2011.

[48] S. Al Muchtar, Inovasi dan Transformasi Pembelajaran Pendidikan, Bandung: Gelar Pustaka Mandiri, 2014.

[49] N. Sedubun, Peladi Maluku Tengah, Retrieved from dihttp://ohoira.blogspot.com/2014/05/pela-di-maluku-tengah1.html. on [2 Maret 2015], 2014

[50] Borg and Gall, Education Research, New York: Allyn and Bacon, 2003.

[51] R. J. Marzano, Dimensions of Thinking: A Framework for Curriculum and Instruction, Alexandria, Virginia: Association for Supervision and Curriculum Development, 1992.

[52] J. R. Fraenkel, How to Teach about Values: An Analytic Approach, New Jersey: Prentice-Hall, Inc, 1997.

[53] T.J. Lasley, D. Siedentop, and R. Yinger, "A Systemic Approach to Enhancing Teacher Quality: The Ohio Model", Journal of Teacher Education, 57 (1), 2006, pp 13-21.

[54] G. Gay, Preparing for Culturally Responsive Teaching, Journal of Teacher Education, 53 (2), 2002, pp 106-116

[55] R. Arends, Learning to Teach, Jogjakarta: Pustaka Pelajar, 2008.

[56] Trianto, Model-Model Pembelajaran Inovatif Berorientasi Konstruktivistik: Konsep, Landasan Teoretis-Praktis, dan Implementasinya, Jakarta: Prestasi Pustaka Publiser, 2007. 